\title{
Social Deixis in English and Tae' Bastem: Revisiting Brown and Gilman's TU and VOS Forms
}

\author{
Nasriandi ${ }^{1}$, Jusriati $^{2}$, Syahrir $^{3}$ \\ ${ }^{1,2,3}$ Universitas Muhammadiyah Palopo \\ E-mail: ${ }^{1}$ nasriandi@ umpalopo.ac.id, ${ }^{2}$ jusriati@umpalopo.ac.id, ${ }^{3}$ syahrir@umpalopo.ac.id

\begin{tabular}{ccc}
\hline Diterima & Direvisi & Disetujui \\
$10-08-2020$ & $26-08-2020$ & $31-08-2020$ \\
\hline
\end{tabular}

\begin{abstract}
This research is attempt to discovers the TU and VOS forms in Tae' Bastem language and in English, TU and VOS form was first discovered by Brown and Gilman in 1960. TU represents the pronoun that is used in informal/familiar situation and VOS is used in a formal/polite situation. However, the writer sees that TU and VOS is cultural and it will differ from culture to culture. The researcher found TU and VOS forms in Tae' Bastem, in fact there are six second person pronoun found in Tae' Bastem,pronoun pronoun "ki", and "ta", pronoun " $k i$ ", and "ta" are used in formal situation or in polite speech, and pronoun "ko" and "mu" are used in informal or impolite speech. Another finding that the writer found is in Tae' Bastem, there are two pronoun which are used in both situation, whether in informal or formal, polite or impolite speech, which are the pronoun "mi" and "kun", pronoun "mi" and "kun" are used in polite or impolite speech. Otherwise, TU and VOS are not found in English, even in the southern English in America, the only second person pronoun which exist in English is "YOU", and it is used both in formal/informal or polite/impolite situation. However English speaker, especially those who live in southern part of the United states of America, they have their own way in order to distinguish utterances in formal or informal, in formal situation or in polite speech which are; to say "please" when asking for something, to say "thank you" before or after, saying "yes ma'am" "no ma'am", soft spoken, maintaining eye contact, and even always be aware of voice tone.
\end{abstract}

Keywords: Brown and Gilman, TU and VOS forms, second person pronoun

Abstrak - Penelitian bertujuan untuk menemukan bentuk TU dan VOS dalam bahasa Tae 'Bastem dan dalam bahasa Inggris, bentuk TU dan VOS pertama kali ditemukan oleh Brown dan Gilman pada tahun 1960. TU mewakili kata ganti yang digunakan dalam situasi informal / akrab dan VOS digunakan dalam situasi formal / sopan. Namun, penulis melihat bahwa TU dan VOS tergantung pada budaya dan akan berbeda dari satu budaya ke budaya lainnya. Peneliti menemukan bentuk TU dan VOS di Tae 'Bastem, bahkan ada enam kata ganti orang kedua yang ditemukan di Tae' Bastem, kata ganti kata ganti "ki", dan "ta", kata ganti "ki", dan "ta" digunakan secara formal atau dalam situasi sopan, dan kata ganti "ko" dan "mu" digunakan dalam situasi informal atau tidak sopan. Temuan lain yang ditemukan penulis adalah di Tae 'Bastem, ada dua kata ganti yang digunakan dalam kedua situasi, baik dalam situai informal atau formal, sopan atau tidak sopan, yang merupakan kata ganti "mi" dan "kun", kata ganti "mi" dan "kun" digunakan dalam situasi sopan atau tidak sopan. Sedangkan TU dan VOS tidak ditemukan dalam bahasa Inggris, bahkan di Negara bagian selatan Amerika, satu-satunya kata ganti orang kedua yang ada dalam bahasa Inggris adalah "YOU", dan digunakan baik dalam situasi formal / informal atau sopan / sopan. Namun penutur bahasa Inggris, terutama mereka yang tinggal di bagian selatan Amerika Serikat, mereka memiliki cara mereka sendiri untuk membedakan ucapan dalam formal atau informal, dalam situasi formal atau sopan; untuk mengatakan "please" ketika meminta sesuatu, untuk mengatakan "thank you" sebelum atau sesudah, mengatakan "yes ma'am" "no ma'am", berbicara dengan lembut, menjaga kontak mata, dan bahkan dengan nada suara.

Kata Kunci : Brown dan Gilman, Bentuk TU dan VOS, Kata Ganti Orang Kedua

\section{INTRODUCTION}

There are good reasons why all languages have deictic terms. A language without such terms could not serve the communicative needs of its users anything as well as real human language. So it is obvious that to reach the goal of communication, all real human languages must have such deictic terms. In modern linguistic studies as according to(Levinson, 1983) Deixis is an important field studied in Pragmatics, Semantics and Linguistics. Deixis also seems critical for our 
ability to learn a language, which philosophers for centuries have thought to be closely linked to the possibility of ostensive definition.(Hanks \& Hanks, 2017)

Deixis has five categories, they are: person, place, time, discourse and social deixis. The first three are traditional deixis and the last two are other types of deixis which are related with the first three, and introduced by Fillmore and Lyon, later followed by Levinson. One of the most important deixis category is Social deixis, since it is concerned with the social information fixed within different expressions, such as close social relations and familiarity. The two types of social deixis are honorifics and the Tu and Vous form which was introduced by(Brown \& Gilman, 1960), Their study showed that such forms are governed by power, adopted symbols $\mathbf{T}$ and $\mathbf{V}$ as designators for respectively a 'familiar' and 'polite' approach, in a parallel with Latin subject pronouns tu and vos, where tu was the familiar pronoun of address directed at one person and Vos was for a polite approach directed at one person, as a sign of reverence, was also the invariable plural, both familiar and polite.

(Brown \& Gilman, 1960) suggested that the use of the familiar pronoun $\mathbf{T}$ and deferential pronoun $\mathbf{V}$ in European languages were governed by two forces; power and solidarity. It is argued that solidarity is mostly expressed in reciprocal use of either $\mathbf{T}$ or the $\mathbf{V}$ pronoun, while power is expressed in nonreciprocal use of pronouns between the more and less powerful in communication. The plural form is thus used as a way of expressing formality, respect or social distance. On the other hand, solidarity implies intimacy and is reciprocal. Thus, based on this hypothesis if the interlocutors are close and intimate with each other, they will mutually exchange $\mathbf{T}$.

Today, over half a century since Brown and Gillman's Theoretical model was first published, Symbols T and V are still being used. The alternatives they represent, however, may have come to stand for a formal/informal dichotomy $(\mathrm{V} / \mathrm{T})$, instead of the original 'polite' (V) and 'familiar' (T) interpretation(Cook, 2014). As highlighted by Brown and Gillman, in modern English, there is only one pronoun of address, unlike the non-reciprocal interaction of $\mathrm{T}-\mathrm{V}$ pronouns, single 'You' is used reciprocally between old and young, rich and poor, monarch and citizen, and so on, thus bridging across possible social divides such as age, wealth, birth and others.(Cook, 1997) Which then explained later again in another article regarding Portuguese Language (Cook, 2013).
However, deictic is so cultural, thus every culture has its own uniqueness, and so does the Tu and Vos forms. The phenomenon of deixis has been taken to be the clearest single example of language's embeddedness in context. However, contexts explored in the study of deixis have come to be restricted to those that are phenomenally immediate, rather than to those that represent the broader indexical order of society.(Manning, 2001)Tae' language which is one of the local languages in south Sulawesi has its own cultural context in which the Deixis system built up. But the unique thing about Tae' language is there more than one variations of this language, for example, Tae' Palopo, Tae' Masamba, and Tae' Bastem. This research will focus on Tae' Bastem, Tae' Bastem is a language which is spoken by people in Bastem area, Basse santempe or Bastem is an area which is located in a valley east side of Latimojong, Luwu regency, South Sulawesi. There are 10 language groups in Luwu regency which are; Tae', Pamona, Limolang, Toraja Sa'dan, Rampi, Seko, Wotu, Padoe, and Java (Transmigrants language group). Tae' language consists of four dialects which are; Rongkong, South Sulawesi, North Luwu, and Bua. Tae language spreads in some of areas such as; Larompong, Suli, Belopa, Bastem, Bupon, Bua, Walenrang, Bone-Bone, Wotu, Mangkutana, and Malili.

A previous study done by Maghfirah Tayyib on Deixis in Bahasa Tae' and English ( a Pragmatics Contrastive Analysis) but according to the pre-observation and experience by the researcher found that even Tae language that is spoken by Palopo and Bastem are the same language due to a high mutual intelligible between those two variations but there are still some differences in those variations including deixis(Magfirah_Pebruari 2014, n.d.).stated that English does not have such pronouns deals with social deixis. Instead, English employs person deixis serving as vocative, in denoting the social relationship of the interactants, for example: 'you', 'Susie', or 'Sir Robert'. In contrast, Tae' language has social deixis in the form of pronoun as shown in the previous part of person deixis. There is the pronoun kita' for second person both singular and plural social. The pronoun kita' is used instead of 'iko and kamu' for those who are older, respected, honored, nobleman, or in high class status. It is also considered more polite than others. However, based on the writer's pre observation, it is found that in Social deixis especially on the Tu and Vos form of Tae' Bastem contain more than polite or impolite social deixis. also based on the existing studies, it is assumed that deixis system of local languages in east Indonesia is sometimes quite sophisticated. The form of the expression is more than one and the variation of the system is numerous. Furthermore, from the pre-observation and 
experiences by the researcher, there are differences from Tu and Vos forms by Brown and Gilman, which can be explained from the data below:

\author{
Anak : umba ra mi ola male pa'? \\ Daughter: where are you going dad? \\ Bapak : lian Padang Sappa. \\ Father: I want to go to Padang Sappa. \\ Anak : apa omo la ta ala male lian? \\ Daughter: what are you going to do there? \\ Bapak : den kabottingan, anak na sindo indo \\ sukma la botting, dau mi salai banua le... \\ Father: There is a weding there, Mrs.Sukma's \\ daughter, don't you leave the house!
}

\section{Nenek : dau mu alloi to pakaiangmu, Laurang} mai.

Grandma: do not drying your clothes, it's going to rain.

Сucu : sattu sia ri ne... la di alangkun raka

pakaiangmi?

Grand son: only a minute, grandma... do you want

me to get your cothes?

Nenek : iyo, la uran mai

Grandma: yes, it is going to rai.

Сиси : еeе... buda liu sirring

Grandson: eee... there are a lot of ants

Nenek : dau mu kaccai, tae ran a kengke ko.

Grandma: do not bother them, they won't bite you.

From the data above, it is shown that Tae' Bastem also has $\mathrm{Tu}$ and Vos forms, which are kita or $\boldsymbol{t a}$ represents $\boldsymbol{T u}$ and iko or ko represents Vos, and also from the data above, there is another form which is exist or occur in both occasions, formal and informal or polite and impolite which is $\mathbf{m i}$. while in English there is no $\boldsymbol{T u}$ and vos Forms, in fact there is only one second person pronoun deixis which is You. This is then become a problem, especially for the Tae' Bastem's speakers, according to the interview which was done by the researcher with Tae' Bastem speakers, they think that English language is an impolite language since they only use one second person deixis when they talk to others, whether they talk to older or younger people, and actually this is a problem, especially for those who wants to learn English.

\section{METHOD}

In this research, descriptive qualitative method was used to find out the Social deixis TU and VÕS form which are used in English and Tae' Bastem and to explain the different between the social deixis TU and VÕS form in English and in Tae' Bastem as well. Descriptive qualitative is a mehod of research which the questions are to be investigated require an understanding of processes, events, or relationship based on qualitative data. In regard with this current research, the descriptive qualitative design matches the aims of this research, which is to describe the use of $\mathrm{T} \& \mathrm{~V}$ form in English and Tae' Bastem. Qualitative as research procedure produces descriptive data involving oral and written data from people and behaviour that can be observed (Huda et al., 2017)

There are two types of data which are used; primary and secondary data. The source of the data in this research is the American Society in Pineville, Louisiana. The writers elaborated the utterances which were recorded from daily conversation and beside that, the writers also collected data from Bastem Society, in Luwu. The writers also handed out questionnaires as well in order to find out the strategies behind the usage of $\mathrm{Tu}$ and Vos form in both languages.

The data were collected by note-taking technique, recording and questionnairre for both of English and Tae' Bastem Data. Sudaryanto in Muhammad stated that in collecting data, the aims of the observation should be explicit. In addition, there should be at least three steps that the researcher applies, collecting, choosing, classifying as well as arranging. In collecting the data in this research, the researcher used several steps, the first step is recording the Natural conversation which is done by Bastem communities. And for the English data, they were taken by recording the natural conversation as well which were done by American community in Lousiana. The recording was taken by using smartphone in various circumstances. After recording, all recordings were collected and then the writers chose the data which contain the Social deixis $\mathrm{Tu}$ and Vos forms to be analysed. The additional data, the researcher handed out questionnaire. As for the additional data, the writers handed out questionnaire via social media to a family member in Louisiana, USA. The Questions used for the questionnaire are;

1. In your point of view, what are the characteristic of polite language/utterances? (mention as many as possible)

2. In your point of view, what are the characteristic of impolite language/utterances? (mention as many as possible)

3. When you are talking to your best friend/close friend, what kind of language variation do you use?
a. Polite or respectful. b. Casual or informal
c. Combination of both 
4. When you are talking to your friend (not close), what kind of language variation do you use?
a. Polite or respectful. b. Casual or informal
c. Combination of both

5. When you are talking to somebody that you just met who is older than you, what kind of language variation do you use?
a. Polite or respectful. b. Casual or informal
c. Combination of both

6. When you are talking to somebody that you just met who is younger than you, what kind of language variation do you use?
a. Polite or respectful. b. Casual or informal
c. Combination of both

7. When you are talking to somebody that you just met who has same age as you, what kind of language variation do you use?
a. Polite or respectful. b. Casual or informal
c. Combination of both

8. When you are talking to your Boss, what kind of language variation do you use?
a. Polite or respectful . b. Casual or informal
c. Combination of both

9. When you are talking to your Boss who is younger than you, what kind of language variation do you use?
a. Polite or respectful. b. Casual or informal
c. Combination of both

10. When you are talking to your employee, what kind of language variation do you use?
a. Polite or respectful. b. Casual or informal
c. Combination of both

11. When you are talking to your mother/father, what kind of language variation do you use?
a. Polite or respectful. b. Casual or informal
c. Combination of both

12. When you are talking to your uncle/aunt, what kind of language variation do you use?
a. Polite or respectful b. Casual or informal
c. Combination of both

13. When you are talking to your grandmother/grandfather, what kind of language variation do you use?
a. Polite or respectful. b. Casual or informal
c. Combination of both

14. When you are talking to your relative who is younger than you, what kind of language variation do you use?
a. Polite or respectful b. Casual or informal
c. Combination of both

15. When you are talking to your relative who has same age as you, what kind of language variation do you use?
a. Polite or respectful b. Casual or informal
c. Combination of both

16. In your point of view, what factors which make someone speaks polite/respectfully? (mention as many as possible)

17. Please explain your answer in number 16 .

18. In your point of view, what factors which make someone speak impolite? (mention as many as possible)

19. Please explain your answer in number 18 .

The respondents of the questionnaire were residents of Pineville, Louisiana USA from various ages, educational backgrounds, and Jobs. The result of the questionnaire then concluded the speech used by American who lives on the Southern part of the USA and are discussed on this section.

In analysing the data, the writers used descriptive qualitative method, this method is used to find the Tu and Vos form in English and Tae' Bastem based on the data that will be collected. At this point, the aims of the research is to solve the problems which become the focus in this research in order to know the result of the research, the writers analysed the data through the following steps: Transcribing English and Tae' Bastem into written language, Translating the Tae' Bastem data into English, Analysing the data qualitatively and present them descriptively, the data will be analysed according the occurrences in the sentence, 
and then Comparing the English and Tae' Bastem data.

\section{FINDINGS AND RESULTS}

The descriptive qualitative design matches the aims of this research, which is to describe the use of T \& V form in English and Tae' Bastem. Qualitative as research procedure produces descriptive data involving oral and written data from people and behaviour that can be observed (Huda et al., 2017)

\section{a. TU and VOS form in Tae' Bastem}

\section{Pronoun “ $k i$ ”}

The first pronoun in Tae' Bastem which represent the VOS form is the pronoun " $k i$ ". According to the data which the researcher found;

man: ya tonna... duang allo la mattossok tau... tama na rumah sakit (I went to the hospital two days before the election day)

woman: ya... terakhir ki tama to' le... (that's the last time you went, right?)

The data above shows that it is a communication between a woman, and two men. The context behind this utterances is there were man and woman who are wife and husband, they came to a man's house who is older than both of them, the man started the conversation by saying that He went to the hospital two days before election day, and the woman who is younger the man replied by saying ' terakhir ki tama to le'.( that's the last time you went, right). So, the woman emphasized to the man that it was the last time the man went to the hospital, but from the woman's utterance she used the pronoun $k i$ which referred to the man. Which means that the woman using VOS form when she talk to the man because the man is older than the woman. Thus, she is being polite.

\section{Pronoun " $t a$ "}

1. A: umba la ta ola te ke allo minggu? (where do you want to go on Sunday?)

B: Batustanduk (Batusitanduk)

A: na rencana ta la tarru ki rokko to? (and do you plan to go straight down there?)

B: ee la tarru na tama masiang ke tae halangan (I want to go straight there if there is no problem)

This data shows a conversation between a mother and her son. They were talking about their planning for weekend. The son said "umba la ta ola te' allo minggu?". From this utterance it is obvious that a son should be polite to his mother, and on this utterance shows that the son was being polite towards his mother by using VOS form which in tae' bastem he used the pronoun "ta".

\section{pronoun “ $k o$ ”}
A: jurusan... jiong ko MAN toh? (what department? You go to MAN, right?)
$\mathrm{B}$ : iye (yes)

The data shows a man who is about 50 years old was talking with a boy who is about 20 years old. They are relatives. From the conversation, the man was making sure about the boy's high school by saying "jiong ko MAN toh?". (you go to MAN right?). from the man's utterance, he used the TU form in Tae' bastem which is "ko", and it is also implied that the man was using informal language since he was talking to his younger relative and the boy replied by saying "iye"(yes) which is shown that he is being polite since $\mathrm{He}$ is talking to an older man.

\section{Pronoun “ $m u$ ”}

A: jurusan apa mu ala jiong?( what department do you take at school?)

B: IPA(science)

Beside the pronoun "ko", in Tae' Bastem people also use the pronoun "ko" to refer to the younger people or to use in informal situation. On this data, it is shows that there were two people were talking, one man is about 40 years old and the other is about 22 years old. The older man asked the younger man by saying "jurusan apa mu ala jiong?". From this utterance, the man used the pronoun "mu" referring to the younger man.

\section{Pronoun " $m i$ "}

A: tae 'mo mi tandai na om?( don't you recognize me, uncle?)

B: tae' tongan mo ra ku kilalai kua.... enda ki'?(

No, I do not really remember who you are)

This data shows two men that know each other, but they have not met for a very long time, and they met in an office, one man is about 70 years old and the other is about 45 years old. In this data, the younger man said to the older man "tae'mo mi tandai na om". (you do not recognize me, uncle?), on this utterance the man used the pronoun "mi" to refer to the older man. And then the older man replied 'tae' tongan mo ra ku kilalai kua... enda ki".' (no, I do not really remember who you are), from this utterance the older man used the pronoun "ki" referring to the younger man since $\mathrm{He}$ did not recognize the person. However, according to the data, the pronoun "mi" is not only used in 
formal or polite situation but also others data shows the use of pronoun "mi" in informal/impolite situation or speech;

\section{A: maballo pale to mi ngai appa den ya sambunganna jiong (your school is a good school since you can continuo your study there) \\ B: anu ri ke... bayar jiong (it's just... it's just that we only pay the fee there)}

The data above shows that it is a communication between a 50 years old man and 20 years old man, this data was taken from the same conversation from data (9) and (10). the different is on the data (9) and (10) above, the man is using the TU form in tae' bastem which is the pronoun "ko" (you). But on this conversation, the man use another type of pronoun, on this conversation the man was telling his relative that the school he went to was a good school by saying "maballo pale to $\mathrm{mi}$ ngai appa den ya sambunganna jiong”. (your school is a good school since you can continuo your study there).from this utterance the man was using the pronoun "mi".

\section{Pronoun “kun”}

In Tae' Bastem, it is not only pronoun "mi" that is used in formal and informal situation or polite or impolite speech, but, there is also another pronoun which is used in both of the situation as well, it can be seen in data below;

A: pirang allo mu kun?( how many days already?) $\mathrm{B}$ : tanggal dua ampat na dihitung (it is counted by the twenty fourth)

This is another data which shows another pronoun which can be used in formal/informal situation or polite/impolite utterances. From the data above, a man who was 52 years old was talking to a man who was about 36 years old, the older man wanted to know how long has the younger man been working by saying "pirang allo mu kun" (how many days already?). from this utterances the older man was using the pronoun "kun" referring to the younger man. As it is explained above, pronoun "kun" is also used in polite speech;

A: ohh langsung mukun jammai?( oh, so you went straight here?)

B: iya... karna buda sia oto, na kami te’ mesa memang kan oto, jadi tae' mo ki lempang rekke(yes, because there were many cars, and we are in one car so we didn't stop by there)

This conversation also shown the usage of pronoun "kun". On this conversation there were two men, 03 is about 35 years old and 1 is about 55 years old. They are relative, this conversation occurred at the older man's house. The younger man asked the older man by saying "langsung $m u$ kun jammai?" (so you went straight here?). from the utterance the younger man used the pronoun "kun" referring to the older man.

\section{b. TU and VOS in english}

According to the data which are taken from daily conversation of English speaker in Louisiana, United states of America, it is found that there is no TU and VOS form in English. As the English speakers only use on pronoun which is the pronoun "You" as it shows in data below;

Teacher: Ok...that's what you get don't complain, I like that

Student (Eva): ah..it's like ah... when you say....

The data shows that there is a female teacher at Sunday school, she was teaching her students about complaining and memory verse. There were about ten students at her class, they are about 6 years old. The teacher was asking the student about complaining, and one of her student said " don't complain", and then she replied "ah ok that's what you get, don't complain I like that, ok Eva.." from this utterance, she referred to her student with the pronoun "You", and then the student name Eva answered "ah..it's like ah... when you say...." This utterance also, Eva used the pronoun "you".

\section{Waitress: what you like to drink for y'all today? \\ Man: water, No lemon, please waitress: for you, ma'am?}

In this situation, there were wife and husband at a restaurant, they were about to order food, and then the waitress came and asked about the food and the drink that the couple want. On this data, the waitress said to the man "what you like to drink for y'all today?" from this utterance the waitress used the pronoun "you" referred to the man and then she also used another pronoun "you" but she added "all" in referring to the couple. And also the waitress also said "for you, ma'am?" on this utterance, the waitress used the pronoun "you" in referring to the woman (the wife) but she then used "ma'am" at the end of the utterance in order to be polite since she was talking to customer.

\section{Man: do you wanna put your face outside?}

\section{Woman: I wanna see what will happen}

this data shows the situation where there are couple, young couple. The man is a pilot for a company, and he was at an airplane with his girlfriend. He was teaching his girlfriend how to fly an airplane while they also wanted to see the view 
from up there. They were having a conversation at the air plane, the man asked his girlfriend "do you wanna put your face outside?". From this utterance, the man used the pronoun "you" referred to his girlfriend.

\section{A: you see that short top mountain straight? \\ B: it's a little bit to the left.}

\section{A: I know but you see that one ahead?}

B: yes sir

In this data is the same situation on data (d) where a young couple flew on a plane, but this time they were flying with an instructor. Behind them. They young couple were having conversation and then the instructor said to them "you see that short top mountain straight?". This utterance, the instructor used the pronoun "you" referred to the couple, and then the man replied that the mountain is a little bit to the left, and the instructor then replied "I know but you see that one ahead?". On this utterance the instructor used the pronoun "you" but this time he was referring to only the man since he was the one who replied the instructor and the man said "yes sir". From this man's utterance, he is being polite to the instructor by using "sir" at the end of his sentence since he was talking to an instructor and even older than him as well.

In all the English data above, all the speaker whether in formal/informal or polite/impolite situation, the speakers always use the pronoun "You". However, English speakers have their own way in order to distinguish between polite and impolite speech. According to the questionnaire on the category of polite speech which were handed out to the English speaker in Louisiana, USA. It is concluded that polite speech to say "please" when asking for something, to say "thank you" before or after, saying "yes ma'am" "no ma'am", soft spoken, maintaining eye contact, and even always be aware of voice tone. According to (Bohnemeyer, 2015) Deictic signs symbolically denote some aspect or component of the speech situation - the extra-linguistic context in which they are used, such as the speaker, time, or place of an utterance. Although they are symbolic as types, their tokens in specific contexts represent the particular component of the speech situation indexically.

\section{CONCLUSION}

TU and VOS forms as explained by Brown and Gilman is also found in Tae' Bastem language, however, in Tae Bastem, it is found that there are six pronoun, which represent TU and VOS. VOS is represented by pronoun " $k i$ ", and " $t a$ ", and TU is represented by pronoun " $k o$ " and " $m u$ ". Pronoun " $k i$ ", and " $t a$ " are used in formal situation or in polite speech, and pronoun " $k o$ " and " $m u$ " are used in informal or impolite speech. Another finding that the writer found is in Tae' Bastem, there are two pronoun which are used in both situation, whether in informal or formal, polite or impolite speech, which are the pronoun "mi" and "kun", according to the data above, pronoun " $m i$ " and "kun" are used in polite or impolite speech.

However, TU and VOS are not found in English, even in the southern English in America, the only second person deixis which exist in English is "YOU", and it is used both in formal/informal or polite/impolite situation. Even though in English, there is only one pronoun that is used both in formal/informal or polite/impolite situation which is pronoun "you". However English speaker, especially those who live in southern part of the United states of America, they have their own way in order to distinguish utterances in formal or informal, It is concluded that polite speech to say "please" when asking for something, to say "thank you" before or after, saying "yes ma'am" "no ma'am", soft spoken, maintaining eye contact, and even always be aware of voice tone. However, this research need to be enriched, Thus the writers suggest for other researchers to conduct researches on the same field of study or the same language, which there are only a few researches which have done on Tae' Bastem, Thus it is really difficult to find references regarding Tae' Bastem Language.

\section{REFERENCES}

Bohnemeyer, J. (2015). Deixis. In International Encyclopedia of the Social \& Behavioral Sciences: Second Edition. https://doi.org/10.1016/B978-0-08-0970868.52031-5

Brown, R., \& Gilman, A. (1960). Brown, R., \& Gilman, A. (1960). The Pronouns of Power and Solidarity. In Style in Language (pp. 253-276). The Pronouns of Power and Solidarity. In Style in Language.

Cook, M. (1997). Uma Teoria de Interpretacao das Formas de Tratamento na Lingua Portuguesa. Hispania. https://doi.org/10.2307/345821

Cook, M. (2013). Portuguese Pronouns and Other Forms of Address, from the Past into the Future - Structural, Semantic and Pragmatic Reflections. Journal of Lusophone Studies. https://doi.org/10.21471/jls.v11i0.84 
Cook, M. (2014). Beyond T and V - Theoretical reflections on the analysis of forms of address. American Journal of Linguistics.

Hanks, W. F., \& Hanks, W. F. (2017). Deixis and Pragmatics. In Oxford Research Encyclopedia of Linguistics. https://doi.org/10.1093/acrefore/9780199384 655.013 .213

Huda, A. M., Bajari, A., Muhtadi, A. S., \& Rahmat, D. (2017). Functions and Values of Ritual "Larung Sesaji Kelud" in the local Community of Mount Kelud. Mediator: Jurnal Komunikasi. https://doi.org/10.29313/mediator.v10i2.2744

Levinson, S. C. (1983). Pragmatics. Cambridge textbooks in linguistics. Tü̈bingen: Niemeyer.

Magfirah_Pebruari 2014.(n.d.).

Manning, H. P. (2001). On Social Deixis. Anthropological Linguistics. 